\title{
How feminine is corporate America? A recent overview
}

\author{
Gabrielle Wanzenried
}

Received: 22 December 2004 / Accepted: 3 September 2006 /

Published online: 15 December 2006

(C) Springer Science + Business Media B.V. 2006

\begin{abstract}
The paper provides an up-to-date description of the distribution of female top executives in US corporations across industries and over time. In addition, it characterizes differences in executive compensation practices between men and women. The sample comprises 108,628 observations on 26,047 executives and 2,598 firms from 1992 to 2003. Women are working for smaller, less profitable, faster growing and less risky firms. Furthermore, female executives earn $14 \%$ less than their male colleagues. Finally, the gender pay gap is higher towards the upper end of the pay distribution.
\end{abstract}

Key words female executives · executive compensation · gender pay gap · quantile regressions.

JEL Classification M52 $\cdot \mathrm{J} 31 \cdot \mathrm{J} 82$

\section{Introduction}

How feminine is corporate America? Are there still so few women at the top of the business world, and how has the situation changed over the last few years? Do firms with female executives systematically differ from corporations led by men? And what about money? Do executive compensation practices differ between men and women, and by how much? Are different incentive schemes used to motivate women and men?

The purpose of this study is to provide an up-to-date overview on the status of women in top executive positions of US corporations. It is motivated by a shortage of systematic documentation of an increasingly and widely relevant theme. These and related questions are at the heart of an ongoing discussion about the situation of women in executive

G. Wanzenried $(\bowtie)$

IFZ Institute of Financial Services Zug, University of Applied Sciences of Central Switzerland, Grafenauweg 10, CH-6304 Zug, Switzerland

e-mail: gabrielle.wanzenried@hsw.fhz.ch 
positions in companies. The recruitment and development of women for management positions is nowadays increasingly considered as a bottom-line issue for corporate success. The topic has also been addressed by recent proposals for corporate governance reforms, which aim at increasing board diversity, among other things. ${ }^{1}$ It is more and more acknowledged that diversity has positive effects on board efficiency and its relationships with customers, suppliers and employees [18].

While these issues are commonly discussed in the popular business press, ${ }^{2}$ relatively few academic papers systematically investigate them. Bertrand and Hallock [10], for instance, study the gender compensation gap among high-level executives in US corporations over the period 1992 to 1997 . They find that women have nearly tripled their participation in top executive ranks as well as strongly improved their relative compensation.

Hallock [20] examines the gender wage gap among managers of nonprofit organizations using newly collected data on compensation of managers and accounting characteristics of US nonprofit organizations. He finds significant differences between women and men with respect to both compensation and characteristics of firms they work for.

Bartlett and Miller [8] investigate the influences of networking and human capital investments by examining a sample of top female executives in the US during the 1980s. They conclude that networking is as important as performance variables in helping women to climb the corporate ladder.

This study is an additional contribution to the small, but growing literature on the status of women in the top corporate world. It provides an up-to-date overview of the distribution of women in top executive positions of US corporations across industries, geographical regions and over time. In addition, it attempts to identify firm characteristics that are correlated with female leadership. Finally, it addresses the issue of executive compensation and investigates whether structure and level of executive pay differ significantly between women and men.

The new aspects of the paper are as follows: First, I use recent information up to the year 2003. Current data seems particularly interesting for these kinds of studies given that changes have occurred over the last few years. Besides firm size and profitability, on which the existing literature tends to focus, I systematically focus on a wider set of firm characteristics that are potentially significant for describing the distribution of women in top executive positions. Finally, I use a quantile regression framework for analyzing differences in executive compensation between men and women. This allows me to characterize the gender pay gap over the entire pay distribution and to discover new insights on gender issues in executive compensation practices.

The data are taken from the Compustat Executive database, which reports on the top five executives by firm, for the years 1992 to 2003. The main sample comprises a total of 108,628 observations from 26,047 executives and 2,598 firms. My results suggest that there is considerable heterogeneity in the distribution of female executives across industries. While the share of women in top executive positions steadily increased over the years up to $6 \%$ in 2003, the number of female CEOs remained very small. Furthermore, I find a peer effect in the sense that firms with a woman in the CEO positions are more likely to have one or more other women among their top executives. As to firm characteristics, women executives tend to work for smaller, less profitable, but also faster growing and less risky firms. Note that these observations refer to correlations between female leadership and

\footnotetext{
${ }^{1}$ See, e.g., the Higgs Review under http://www.dti.gov.uk/cld/non_execs_review.

${ }^{2}$ See, e.g., The Economist July 16th 1998, Jill-in-a-box; Survey: Women and Work. 
firm characteristics only. Also, female executive are younger than their male colleagues and have been working for fewer years in the company, on average and compared to men in executive positions. Finally, women are paid $13 \%$ less on average, compared with their male colleagues. Also, the pay gap tends to be largest towards the upper end of the pay distribution. Whether this latter observation is driven by the existence of a glass ceiling or by other factors such as gender-specific preferences, the women's family environment or by other person-specific aspects, cannot be answered by the present study.

The paper is structured as follows: Section 2 outlines the theoretical framework from which testable hypotheses are derived. Section 3 describes the data. Section 4 discusses the distribution of women in top executive positions across industries, geographical regions and over time. Section 5 investigates whether firms with female executives systematically differ from companies led by men. The question of compensation differences between male and female executives is explored in section 6 . Section 7 draws conclusions.

\section{Theoretical framework and tested hypotheses}

Following Baldwin et al. [6], I consider a model of the demand for male and female workers in a firm with a simple technology. ${ }^{3}$ Note that the model is simplistic and is only able to give a flavor of the issues considered in the paper, which are much more complex in the real world. I assume that there is hierarchical discrimination against women. The model provides an explanatory framework for the decreasing number of women with higher hierarchy level in organizations as well as for the pay gap between men and women in management positions.

Consider a profit-maximizing firm that hires $L_{M}$ male workers and $L_{W}$ female workers at a wage $W_{L}$, and one supervisor at a wage $W_{S}$, with $W_{S}>W_{L}$. It is assumed that male workers have a distaste to work under female managers. This distaste may originate in social norms, which make it difficult for men to have a woman as a boss. ${ }^{4}$ The distaste can also come from the hiring practices inside corporations, the corporate culture in general or even from the way women treat men. The male workers' distaste for female supervisors is measured by the parameter $\delta$, where $\delta>0$. In case a firm hires a female supervisor, male workers require a wage $(1+\delta) W_{L}$ in order to compensate them for having a woman as boss. Given that firms are minimizing costs, they hire a male supervisor except if all workers to be supervised are women. Accordingly, firms will be segregated except at the lowest entrylevel jobs, i.e., female supervisors will only supervise female workers, whereas male supervisors will be the boss of men as well as women. The total costs of labor are as given by Equation (1).

$$
C=L_{M} W_{L}(1+\delta)+L_{F} W_{L}+W_{S}
$$

The firm is willing to hire a woman to supervise male workers in case she accepts a wage penalty to compensate her employer for the wage differential he has to pay to his

\footnotetext{
3 This model goes back to Becker's [9] model of discrimination.

${ }^{4}$ In 1997, for instance, Fortune Magazine wanted to bring an article about the men behind powerful business women. It was observed that there is an increasing number of men who are in less powerful positions than their wives and that they even stay at home to manage household and family. Interestingly, this article was published only in 2002, because Fortune magazine could not find enough executive women who were ready to talk about the roles of their husbands in 1997. See also Morris [27] and Polacheck [29] for reference.
} 
male workers. Let $p$ be the wage penalty imposed on a female supervisor, expressed as a fraction of a male supervisor's wage. Then, total costs of labor in case of a male supervisor are given by Equation (2), and the corresponding total costs of labor with a female supervisor are captured by Equation (3), i.e.,

$$
\begin{gathered}
C_{\text {male_supervisor }}=L_{M} W_{L}+L_{F} W_{L}+W_{S} \\
C_{\text {female_supervisor }}=L_{M} W_{L}(1+\delta)+L_{F} W_{L}+W_{S}(1-p)
\end{gathered}
$$

It follows that the firm is willing to hire a female supervisor only if the wage penalty $p W_{S}$ offsets the costs induced by the male workers distastes for a female supervisor. Equalizing Equations (2) and (3) leads to the following equality.

$$
p=L_{M} \delta \frac{W_{L}}{W_{S}}
$$

Given Equation (4), the wage penalty $p$ imposed on a female supervisor is larger, (a) the stronger the male workers' distastes for female supervisors, (b) the larger the share of male workers, and (c) the higher the workers' wage relative to the supervisor's compensation. It follows that a firm is more likely to hire a woman instead of a man for the position of supervisor if the number of men to be supervised is small and the wage differential between the supervisor and the workers is relatively large. Note that the hierarchical discrimination reduces the mean wage of women in the following two ways: First, there is an occupational effect: Fewer women are working in managerial positions. Second, there is a wage effect, in the sense that at each management level, female wages are reduced by the implicit compensation the female manager pays to her employer in order to cover the discriminatory employment cost.

The model of hierarchical discrimination allows me to formulate the following hypotheses.

\section{Hypothesis 1 The relative number of females is smaller at higher hierarchy levels.}

Hypothesis 2 Female supervisors prefer having female workers instead of male workers, given the wage penalty induced by the latter.

Hypothesis 3 Female managers earn less than their male colleagues.

Given that the number of male workers is likely to be correlated with the total number of workers in a firm, the predictions of the model lead to an additional hypothesis:

\section{Hypothesis 4 Female managers tend to work for firms with a smaller number of employees.}

In what follows, I investigate the role of women in top corporate functions of US companies. Given that my data include observations from the highest hierarchical management positions only, I cannot fully test the predictions of the model, but only provide some empirical evidence which may at least not be inconsistent with the predictions of the simple model considered above. Note also that the main results of the theoretical model critically depend on the underlying assumption according to which men have a distaste to work for women. Note, however, that this assumption can be interpreted in several ways, and it is therefore able to capture a rather wide range of possible real world situations and does not seem so unrealistic. 


\section{Data description}

The main data source is the Compustat Executive Compensation database that includes compensation data from the top five executives of companies within the S\&P 1500 for the years 1992 to 2003. Originally, there are 128,575 observations from 26,088 executives and 2,598 firms in the database. I keep all the observations for which there is non-missing information for the main compensation measures such as salary, bonus, options and other. This leaves a total of 108,628 observations from 26,047 executives and 2,598 firms that form the main sample (sample 1).

When looking at the relationship between the share of women and firm characteristics, I combine the data on executive compensation with financial statement information taken from the Compustat Industrial Annual database over the same time period. Given that not all the firmspecific information is available for the companies in the main sample, all the observations with missing data for one or more firm characteristics have to be removed from the sample, leading to 75,129 observations from 17,783 executives and 1,632 firms (sample 2). The regression analysis in section 5 of the study is based on firm data. Therefore, I collapse sample 2 such that there is one observation per firm and year. This results in sample 3 with 14,417 observations from 1,632 firms. Note that the reduction in the total number of observations is only due to the fact that the total number of observations in sample 2 refers to the number of executives, while it refers to the number of firms in sample 3.

Finally, the regression analysis of earnings differentials between men and women in section 6 uses information about age and tenure of executives, which is available for a restricted number of executives only. Based on sample 2, I keep all the observations with non-missing values for the variables included in the earnings regressions. This leads to sample 4 , which comprises a total of 12,771 observations from 1,802 executives and 1,111 firms. Summary statistics of the variables from the specific samples are reported in the following sections. The data are deflated using the consumer price index and reported in US dollars (2003).

\section{How widespread are female executives?}

This section provides an overview on the distribution of female executives among the top five executives in corporate America. A first look at the data tells us that female executives form a clear minority. Table I reports the absolute and relative number of women in top executive positions in our main sample (sample 1). There are $5.2 \%$ female executives in the sample, and the proportion of female CEOs is as low as $1.77 \%$. Note that the difference

Table I Women by executive category

\begin{tabular}{llllll}
\hline & \multicolumn{2}{c}{ CEOs } & & \multicolumn{2}{l}{ All executives } \\
\cline { 2 - 3 } \cline { 5 - 6 } \cline { 5 - 6 } & Nb. of executives & Nb. of observations & & Nb. of executives & Nb. of observations \\
\hline All & 2,545 & 16,600 & & 26,047 & 108,628 \\
Women & 45 & 256 & & 1,354 & 4,342 \\
Share of women in $\%$ & $1.77 \%$ & $1.54 \%$ & & $5.20 \%$ & $4.00 \%$ \\
\hline
\end{tabular}

The table reports the number of executives and observations as well as the share of women both for CEOs and for all executives. The sample includes a total of 108,628 observations covering 26,047 executives and 2,598 companies (sample 1). The time period covers the years from 1992 to 2003. The datasource is the Compustat Executive Compensation database. 


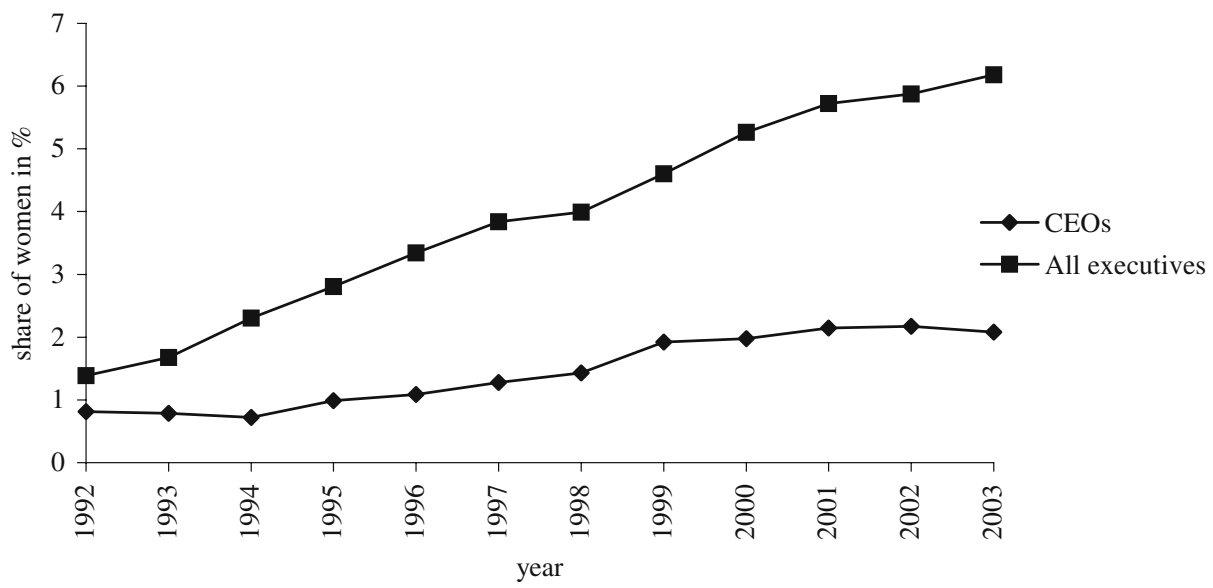

Figure 1 The figure reports the share of female executives and the share of female CEOs over time. The sample includes a total of 108,628 observations covering 26,047 executives and 2,598 comapnies (sample 1). The time period covers the years from 1992 to 2003. The datasource is the Compustat Executive Compensation database.

between the shares referring to the number of executives and the number of observations, i.e., $5.2 \%$ vs. $4.00 \%$ for all executives, and $1.77 \%$ and $1.54 \%$ for women, has to do with the fact that the average number of observations per executive is smaller for women in comparison to all executives in the sample. In particular, there are 6.52 observations for each executive on average, while the average number of observations of female executives in the sample amounts to 5.69.

The observations summarized by Table I can be interpreted as support for hypothesis 1 , as outlined in section 2. given that the CEO position is the highest hierarchical level and that the share of women is significantly lower than for all executives.

Given that I am also interested in the changes over time, Figure 1 shows the share of female CEOs and female executives over the time period considered. A positive trend can be observed for both series, but it is much stronger when looking at all executives together. While the share of women in the category all executives increased from $1.39 \%$ in 1992 to $6.18 \%$ in 2003, the corresponding percentage for female CEOs rose from $0.81 \%$ in 1992 to $2.15 \%$ in 2001 only, and it even decreased from then on during the two following years to $2.08 \%$ in 2003 . I conclude that the share of women in executive positions of listed US companies has steadily increased over the last 11 years, but this does not hold for women in CEO positions, whose share has increased a lot less and is still very small., ${ }^{5,6}$

As Burke [14] and Davies-Netzley [16] outline, social networks and peer similarities are facilitating promotion effects. Accordingly, a company that already has a female executive on the board is more likely to promote another woman to the executive rank. In case there is such a peer effect among women in my data, I expect the share of female executives,

\footnotetext{
${ }^{5}$ As Catalyst, a New York-based research nonprofit research and advisory organization working to advance women in business, reports in its 2002 Census, $15.7 \%$ of corporate officers in the Fortune 500 are women, up from $12.5 \%$ in 2000 . However, there were only six female CEOs in the F500 in 2002. For further information see also http://www.catalystwomen.org.

${ }^{6}$ It is clear that these figures look less dramatic in the case where smaller and not only publicly traded companies are considered. According to the U.S. Census Bureau, women-owned companies, which are likely to be managed by women also, constituted $25 \%$ of all U.S. firms in 1997.
} 
Table II Gender peer effect among executives

\begin{tabular}{llllll}
\hline $\begin{array}{l}\text { Nb. of female executives in the firm } \\
\text { (without counting the CEO) }\end{array}$ & \multicolumn{2}{l}{$\begin{array}{l}\text { Firms with a woman in the } \\
\text { CEO position }\end{array}$} & & \multicolumn{2}{l}{$\begin{array}{l}\text { Firms with a man in the CEO } \\
\text { position }\end{array}$} \\
\cline { 2 - 3 } & Nb. of firms & Share in $\%$ & & Nb. of firms & Share in \% \\
\hline 0 & 36 & 46.15 & & 2,598 & 69.19 \\
1 & 28 & 35.90 & & 910 & 24.23 \\
2 & 12 & 15.38 & & 2,5 & 5.46 \\
3 & 2 & 2.56 & 35 & 0.93 \\
4 & 0 & 0 & 7 & 0.18
\end{tabular}

The table reports the number and share of firms by the number of female executives (without counting the CEO) for firms with a female CEO and for firms with a male CEO. The sample includes a total of 108,628 observations covering 26,047 executives and 2,598 companies (sample 1). The time period covers the years from 1992 to 2003. The datasource is the Compustat Executive Compensation database.

without counting the $\mathrm{CEO}$, to be higher in firms that have a female $\mathrm{CEO}$ in comparison to firms with a man in the CEO position. To see this, Table II reports the number and the relative share of firms by the number of female executives without considering the CEO, and this separately for companies with a female CEO and a male CEO. As one can see, the share of firms with no woman among the top executives (besides the CEO) is as high as $69 \%$ for the companies led by a man, but this share is only $46 \%$ for the companies with a woman in the CEO position. Similarly, the share of firms with one, two and three female executives is much higher for the latter group.

Table II provides some evidence that the share of female executives is higher in firms with a woman in the CEO position compared companies with a male CEO. Given the descriptive nature of this statement, I still cannot be sure whether a woman in the CEO position indeed attracts more of her peers, or whether this observation is driven by some other mechanism. To show this more rigorously, I use a simple regression model for which I collapse sample 1 such that there is only one observation per firm and year. This leaves me with a sample of 21,106 observations of 2,598 firms. ${ }^{7}$ I then regress a dummy variable Femlplus_withoutCEO, which is equal to one if there is at least one woman among the top 4 executives (without the CEO position) in a given year, and zero otherwise, on the dummy variable CEOfem. The latter variable is equal to one if the CEO has been a woman in the former period, and zero otherwise. Also, I control for firm size, measured by the firms, market value of the former period, for industry affiliation and time effects. These characteristics may affect the likelihood of companies having female executives. ${ }^{8}$ The regression model is given by Equation (5), where $i$ is the firm index, $j$ refers to the industries, and $t$ is the time variable.

$$
\begin{aligned}
& P(\text { Fem1plus_withoutCEO } \mid X)=P_{i t} \\
& =G\left(\beta_{0}+\beta_{1} \text { CEOfem }_{i t-1}+\cdot \beta_{2} \text { Marketvalue }_{i t-1}+\sum_{j} \gamma_{j} I_{j}+\sum_{t} \delta_{t} D_{t}\right) \\
& i=1, \ldots, N \quad j=1, \ldots, J \quad t=1, \ldots, T
\end{aligned}
$$

\footnotetext{
${ }^{7}$ The smaller number of $18^{\prime} 106$ observations reported in Table III has to do with the fact that I include the lag of the independent variables in the regression model.

${ }^{8}$ In Section 4, I consider additional firm characteristics and discuss their potential impact on the distribution of women in top executive positions of corporations in more detail.
} 
The results from probit and logit regressions are given in Table III which reports the marginal effects. The reason for using both probit and logit estimations has to do with the fact that there are so few women in our sample. If the average incidence is close to zero, then logit and and probit estimates may differ more than if the average incidence is away from the tails. I also include the results from a simple OLS regression. The coefficient of the lagged dummy variable CEOfem is positive and significant at the $1 \%$ level, and this holds for all estimation methods. Hence, a company with a female CEO is more likely to have one or more women in the other top executive positions in the following year, compared to a company with a man in the CEO position. This finding is consistent with the existence of a peer effect. Also, note that firm size has a significantly negative impact on the number of women in top executive positions. Therefore, women are less likely to work for larger companies. I will come back to that in section 4.

Note that the existence of a peer effect is consistent with hypothesis 2, stating that female supervisors prefer women working for them instead of men. Even though the hierarchical difference between the CEO and the other executives may be much smaller compared to the gap between a manager and a worker, the CEO may have some power as well as supervisory functions over the other executives.

Even though this result is in line with the descriptive statistics reported in Table II, I cannot interpret it as conclusive evidence for the existence of a peer effect. There may be omitted factors which drive the result or, more likely in my case, which at least affect the findings and introduce a bias. For instance, it is possible that the company's board may have strong preferences for female executives, which would affect both the likelihood of having a female CEO as well as a higher number of female executives outside the CEO rank. As a result, the coefficient of the dummy variable CEOfem would be biased. Given that I have no information on the board members, I cannot explicitly control for this potential effect. The best I can do is trying to estimate the direction of the bias. In this particular case, the effect of such an omitted variable would introduce a positive bias on the coefficient of the dummy variable CEOfem, because it would be the board rather than the female CEO who caused a higher share of female executives. Therefore, the results in Table III may overestimate the peer effect and should be considered with some care.

Table III Peer effects among executives

\begin{tabular}{lll}
\hline P(Fem1plus_withoutCEO $\mid X)$ & Probit & Logit \\
\hline CEOfem $_{\text {it }^{-1}}$ & $0.22^{* *}(0.03)$ & $0.21^{* *}(0.03)$ \\
${\text { Market } \text { value }_{\text {it }-1}}_{\text {Wald } \chi^{2}}$ & $-0.03(*)(0.02)$ & $-0.03(*)(0.02)$ \\
Nb. of observations & $693.74 * *$ & $678.21^{* *}$ \\
Nb. of firms & 18,106 & \\
\hline
\end{tabular}

The table reports results from probit and logit estimations of the effects of a female CEO and firm size on the likelihood that the company has one or more women among the top four executives, without considering the CEO. The dependent variable is the response probability $P($ Fem 1 plus_withoutCEO $\mid X)$, where Fem 1 plus withoutCEO is the number of women among the top four executives except the CEO position. The explanatory variables are defined as follows: CEOfem is a dummy variable that takes the value of one if the CEO is a woman in a given year, and zero otherwise; the market value is expressed in 100,000. The reported values are marginal effects at the mean level of the corresponding variables. Robust standard errors in brackets. Coefficients that are significantly different from zero at the $1 \%, 5 \%$, and $10 \%$ level are marked with **, *, and $(*)$ respectively. Time and industry dummies as well as constant included. The time period covers the years from 1992 to 2003. All data are reported in real 2003 dollars adjusted using the consumer price index. The datasource is the Compustat Executive Compensation database. 
Finally, the distribution of female executives varies considerably across industries also, as shown in Table IV. Female executives are most widespread in the Wholesale and Retail Trade and Healthcare and Social Assistance, but also in Utilities and Information industries. Note that Bertrand and Hallock [10] find a similar ranking. However, their figures that are based on data up to 1997 only, underestimate the importance of women in 'non-traditional' industries such as Utilities and Information. Also, the shares reported above are much higher in absolute terms when considering the most recent data. If one focuses on CEOs only, the proportion of women is much smaller or zero for certain industries. Note that these figures might be affected by company size, which is related to industry affiliation as well as to the share of women executives. I will investigate the role of firm size and its potential interaction with other characteristics in more detail in the following section.

\section{Which firms are managed by women?}

The previous section gave a preliminary picture of the distribution of female executives over time and across industries. To go one step further, I now ask whether firms with female executives have specific characteristics, beside those associated with the industry classification. This question is motivated by observed gender differences in social behavior, management style, risk aversion, investment strategies, and financial decision making. The analysis of gender effects on various forms of behavior can be found in the economic, management, psychological and social literature, and it is also widely discussed in the business press [26].

Based on existing studies on gender issues, I consider the following company characteristics that may be correlated with female leadership.

Table IV Number of executives and share of women by industry

\begin{tabular}{|c|c|c|c|c|c|c|}
\hline \multirow[t]{2}{*}{ Industry description } & \multicolumn{3}{|l|}{ CEOs } & \multicolumn{3}{|c|}{ All executives } \\
\hline & $\begin{array}{l}\mathrm{Nb} \text {. of } \\
\text { persons }\end{array}$ & $\begin{array}{l}\mathrm{Nb} \text {. of } \\
\text { females }\end{array}$ & $\begin{array}{l}\% \text { of } \\
\text { females }\end{array}$ & $\begin{array}{l}\mathrm{Nb} \text {. of } \\
\text { persons }\end{array}$ & $\begin{array}{l}\mathrm{Nb} \text {. of } \\
\text { females }\end{array}$ & $\begin{array}{l}\% \text { of } \\
\text { females }\end{array}$ \\
\hline Agriculture, Forestry, Fishing and Hunting & 8 & 0 & 0 & 78 & 1 & 1.28 \\
\hline Mining, Oil, Construction & 126 & 0 & 0 & 1,222 & 32 & 2.62 \\
\hline Utilities & 122 & 1 & 0.82 & 1,345 & 84 & 6.25 \\
\hline Manufacturing of Food, Tobacco and Textile & 85 & 2 & 2.35 & 1,004 & 47 & 4.68 \\
\hline $\begin{array}{l}\text { Manufacturing of Chemicals, Concrete, Wood, } \\
\text { Metal and Transportation Equipment }\end{array}$ & 697 & 13 & 1.87 & 7,935 & 308 & 3.88 \\
\hline Wholesale and Retail Trade & 194 & 5 & 2.58 & 2,238 & 156 & 6.97 \\
\hline Transportation and Warehousing & 57 & 0 & 0 & 550 & 14 & 2.55 \\
\hline Information & 125 & 3 & 2.4 & 1,409 & 80 & 5.68 \\
\hline Finance and Insurance & 294 & 2 & 0.68 & 2,671 & 145 & 5.43 \\
\hline Personal and Business Services & 163 & 1 & 0.61 & 1,857 & 100 & 5.39 \\
\hline Health Care and Social Assistance & 36 & 1 & 2.78 & 346 & 23 & 6.65 \\
\hline Miscellaneous & 661 & 17 & 2.57 & 5,651 & 392 & 6.94 \\
\hline Total & 2,568 & 45 & 1.75 & 26,306 & 1382 & 5.25 \\
\hline
\end{tabular}

The table reports the number of executives and the share of female executives by industry, both for CEOs and for All executives. The sample includes a total of 108,628 observations from 26,047 executives and 2,598 companies (sample 1). The time period covers the years from 1992 to 2003 . The datasource is the Compustat Executive Compensation database. 
Size of firm According to Bertrand and Hallock [10], women tend to work for smaller firms. I use the sales and the market value of the firm to measure the size of the firm.

Firm performance A number of studies suggest that female managers perform equally well or better than their male counterparts. According to a study of the Standard and Poor's 500 by Covenant Investment Management [24], businesses committed to promoting minority and women workers had a more than two times higher average annualized return on investment over a 5-year period, in comparison with those firms that had the most shatterproof glass ceilings. Similarly, a survey of 22,000 French firms finds that firms managed by women make far more successful managing directors than men, and that these firms managed by women were twice as profitable [21]. Welbourne [32] documents a long-term positive effect between gender and stock and firm performance when considering the effect of women in the top management team on IPO performance. I use the earnings before interest and taxes (EBIT) over total assets as well as the earnings per share as indicators of firm performance.

Risk exposure There is a stereotypical view according to which women are more likely to avoid risky situations. ${ }^{9}$ A number of studies in psychology and economics argue that men and women display different financial decision making and risk aversion profiles. Estes and Hosseini [19], for instance, argue that women are less confident when making investment decisions. Barber and Odean [7] find that men are "overconfident", and as a result have a higher portfolio turnover as compared to women. Also, women tend to hold less risky portfolios in comparison to men. I use two traditional measures that are commonly related to a firm's probability of default [3]. The first variable is the firm's leverage defined as the ratio of long-term debt over total assets. The second variable to approximate a firm's risk exposure is the liquidity measure current assets over current liabilities.

Growth Carter et al. [15] argue that a company's growth is a strategic choice variable that may, among others, also depend on the executives' preferences. From their survey of 22,000 French firms, Hunter and Reid [21] find that companies managed by women grew twice as fast in comparison to firms managed by men. Finally, Welbourne [32] reports a positive relationship between the percentage of women participating in management and a modified Tobin's Q in his study of IPO performance. I measure growth by the Q-ratio, which is commonly used to measure a firm's expected growth and is defined as total assets plus the difference between the market and book value of equity over total assets. ${ }^{10}$ In addition, I use the change in sales from year $(t-1)$ to year $t$ as a measure of past growth.

In contrast to some studies mentioned above, it is important to note that the results reported below refer to partial correlations between the firm characteristics considered and the likelihood that there are female executives, and I am not making any statement about causal relationships. Therefore, I am not able to tell whether a firm has a certain characteristic because it is managed by a woman, or whether a firm hires or attracts female executive because it has this specific characteristic. In order to discriminate between these two possibilities, one needs to control for all other factors that may affect a specific firm

\footnotetext{
${ }^{9}$ See, e.g., Powell, Schubert and Gysler [30] for further references.

${ }^{10}$ See, e.g., Bevan and Danbolt [11].

望 Springer
} 
Table $\mathbf{V}$ Descriptive statistics of the variables in the logit and probit regressions

\begin{tabular}{|c|c|c|c|c|c|}
\hline & & All firms & $\begin{array}{l}\text { Firms with } \\
\text { Fem } 1 \text { plus }_{i t}=0\end{array}$ & 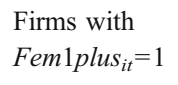 & $\begin{array}{l}P \\
\text { value }\end{array}$ \\
\hline $\begin{array}{l}\text { Firm is 'woman } \\
\text { managed' }\end{array}$ & Fem1plus & 0.16 & 0 & 1 & - \\
\hline \multirow[t]{2}{*}{ Size } & Sales & $\begin{array}{l}3,198.47 \\
\quad(8,659.64)\end{array}$ & $\begin{array}{r}3,189.41 \\
(80.56)\end{array}$ & $\begin{array}{l}3,244.40 \\
\quad(157.58)\end{array}$ & 0.75 \\
\hline & Market value & $\begin{array}{l}4,515.79 \\
(16,884.44)\end{array}$ & $\begin{array}{l}4,550.20 \\
(155.86)\end{array}$ & $\begin{array}{r}4,341.30 \\
(322.76)\end{array}$ & 0.56 \\
\hline \multirow[t]{2}{*}{ Performance } & $\begin{array}{l}\text { Earnings before interest } \\
\text { and taxes /assets }\end{array}$ & $\begin{array}{l}14.01 \\
(12.30)\end{array}$ & $\begin{array}{l}14.14 \\
(0.11)\end{array}$ & $\begin{array}{r}13.37 \\
(0.30)\end{array}$ & 0.01 \\
\hline & Earnings per share & $0.97(2.14)$ & $0.98(0.02)$ & $0.93(0.06)$ & 0.43 \\
\hline \multirow[t]{2}{*}{ Risk } & Long-term debt/total assets & $\begin{array}{l}20.57 \\
(17.41)\end{array}$ & $\begin{array}{l}20.81 \\
(0.16)\end{array}$ & $\begin{array}{r}19.35 \\
(0.36)\end{array}$ & 0.00 \\
\hline & $\begin{array}{l}\text { Current assets/current } \\
\text { liabilities }\end{array}$ & $\begin{array}{l}225.84 \\
(236.37)\end{array}$ & $\begin{array}{r}223.54 \\
(2.07)\end{array}$ & $\begin{array}{r}237.48 \\
(5.75)\end{array}$ & 0.02 \\
\hline \multirow[t]{2}{*}{ Growth } & Q-Ratio & $2.03(1.57)$ & $2.01(0.01)$ & $2.16(0.04)$ & 0.00 \\
\hline & $\begin{array}{l}\text { Change in sales from }(t-1) \\
\text { to } t\end{array}$ & $\begin{array}{l}18.35 \\
(295.66)\end{array}$ & $\begin{array}{l}16.52 \\
(0.73)\end{array}$ & $\begin{array}{l}27.59 \\
(14.47)\end{array}$ & 0.44 \\
\hline
\end{tabular}

The table reports means and standard deviations (in brackets) of firm characteristics over the years 1992 to 2003. Fem1plus is equal to one if there is at least one woman among the five top executives in a given year, and to zero otherwise. The Q-ratio is defined as total assets plus the difference between market value and book value of equity over total assets; $P$ value refers to the difference in sample means between males and female executives (twosided means difference test with unequal variance). The sample includes a total of 14,417 observations from 1,632 companies (sample 3). The time period covers the years 1992 to 2003 . Sales and Market value are in 100,000. All the ratios except the Q-ratio are in \%. All data are reported in real 2003 dollars adjusted using the consumer price index. The datasource is the Compustat Executive Compensation database.

characteristic, and this is not possible with the data at hand. ${ }^{11}$ Also, it is likely that even though it would be desirable and potentially interesting to know about causes and effects in this particular context, the data at hand do not allow to conduct such an analysis, and the results are limited to simple correlations.

In a first step, I check whether, among executives, there are gender differences in the means of the characteristics described previously. I use two-sided means difference tests and allow for unequal variance. This is simply a descriptive exercise which does not control for any industry and time effects or potential interactions between the characteristics considered. In order to have as broad a view as possible, these tests are based on the main sample (sample 1), which, however, does not have the same number of observations for all characteristics. Note that afterwards I repeat the tests with a reduced sample with an identical number of observations for all variables as well as with a collapsed sample based on firm-year and not on executive-year observations. (Table V).

The results from the two-sided means difference tests are as follows: ${ }^{12}$ Female executives work for smaller firms compared to male executives on average, and this holds

\footnotetext{
${ }^{11}$ For the firm characteristic risk, for instance, one would have to control for the main factors that affect a firm's risk exposure. Apart from financial information, which may be available, it also requires information on the firm's age, their revenue history, the experience of the management, the available technologies and the product market strategy, etc., all not easily observable factors.

${ }^{12}$ The results from the two-sided means difference tests are not reported in detail. The corresponding table with summary statistics is available from the author upon request.
} 
for both measures of firm size. This finding is in line with Bertrand and Hallock [10]. Note also that this observation provides support for hypothesis 4 , stating that female managers tend to work for smaller firms. When looking at firm performance, I observe that women work for firms with a lower EBIT relative to total assets as well as with lower earnings per share. This observation is in contrast with the aforementioned studies that find a better performance of companies with more female executives. As far as firms' risk exposure is concerned, I observe that women are more likely to work for firms that are significantly less risky, i.e., companies with a lower leverage and a higher liquidity compared to the men's employers. Such findings do not contradict the presumption made in the literature that men and women differ from each other in terms of risk aversion. Finally, expected growth of firms, as approximated by a version of Tobin's Q, is significantly higher for firms with female executives. When considering the growth of sales, however, the difference between male and female executives is no longer significant. Overall, I find robust results with respect to the gender of executives and firm characteristics for firm size, performance and risk exposure. Again, these statements are limited to partial correlations between the gender and the firm characteristics, and nothing is said about any causal effect.

It is evident that the findings from means difference tests are related to the distribution of women across industries as discussed earlier. Also, certain firm characteristics are not independent of each other. As is known from capital structure studies, for instance, larger firms are also more leveraged on average. ${ }^{13}$ If women are working for smaller firms, and smaller firms have lower debt ratios, then I also find that female executives are more likely to be associated with less leveraged firms.

In order to control for possible interactions and to provide additional evidence on partial correlations between female leadership and firm features, I run logit and probit regressions, where I relate the likelihood that there is at least one woman among the top executives to firm characteristics and industry affiliations considered above. The reason for using both probit and logit estimations has to do with the fact that there are so few women in my sample. If the average incidence is zero, then logit and probit estimates may differ more than if the average incidence is away from the tails.

A firm is considered as 'women managed' if there is at least one woman among the top five executives. Accordingly, the dependent variable is the dummy variable Fem1plus that is equal to one if there is at least one woman among the five top executives in a given year, and to zero otherwise. The variable Fem 1 plus is regressed on the firm characteristics under consideration and on industry dummies captured by $I j$, with the chemical (and other material) manufacturing industries as a benchmark case. I also include year dummies $D t$, with 1992 as base category. The model is given by Equation (6).

$$
\begin{aligned}
P\left(\text { Fem 1plus }_{i t} \mid X\right) & =P_{i t} \\
& =G\left(\beta_{0}+\beta_{1} \text { Size }_{i t}+\beta_{2} \text { Performance }_{i t}+\beta_{3} \text { Risk }_{i t}+\beta_{4} \text { Growth }_{i t}+\sum_{j} \gamma_{j} I_{j}+\sum_{t} \delta_{t} D_{t}\right) \\
i & =1, \ldots, N \quad j=1, \ldots, J \quad t=1, \ldots, T
\end{aligned}
$$

In contrast to the means-difference tests mentioned above, which are based on the observations of executives, the regression analysis refers to the firm as unit of investigation and requires some selections and transformations of the original sample (sample 1). First, I deleted all the observations with missing values for the firm characteristics considered. This

\footnotetext{
${ }^{13}$ See, e.g., Tittman and Wessels [31]. 
reduces the sample to a total of 75,129 observations covering 17,783 executives and 1,632 firms (sample 2). Before making additional transformations, I re-run the means-difference tests in order to check the robustness of the correlations observed in the original sample based on executive observations. The difference for both performance variables EBIT over total assets and earnings per share between male and female executives is no longer statistically significant in this reduced sample, and the same holds for the size proxy Sales. All the other differences, however, remain significant. ${ }^{14}$ In a second step, I collapse sample 2 such that each firm appears only once per year in my sample. This leaves me with sample 3, which includes 14,417 firm-year observations covering 1,632 firms.

Table $\mathrm{V}$ reports the mean and standard deviation (in brackets) of the variables in sample 3, overall as well as separately for the firms without and with at least one woman among the top five executives. The last column shows again the $P$ values from means difference tests between the two groups of firms. The main differences with the results reported previously refer to both size proxies and the profit measure earnings per share, for which the difference between the groups is not any more statistically significant.

Equation (6) is estimated by maximum likelihood, and the corresponding results are reported in Table VI. Note that I directly report the marginal effects at the mean level of the variables considered. I also allow for different specifications with respect to the explanatory variables included, given that the alternative proxies of company characteristics do not exactly measure the same feature. Robust standard errors are calculated according to the Huber/White/Sandwich estimator of variance and are given in brackets. The results in Table VI suggest that smaller and faster growing firms are more likely to have female executives. In addition, women have a higher probability to work for less profitable firms. The alternative firm performance measure, earnings per share, does not exhibit a significant coefficient, and this holds for the logit and probit models. As far as risk exposure is concerned, the estimates confirm the presumption that women work for firms with a lower risk of default, which is reflected in a negative effect of leverage and a positive effect of liquidity on the probability that the firm is managed by one or more women. Let me stress again that I do not conclude that firms are less risky because they are managed by women or that less risky firms attract more women in executive positions. Both growth measures indicate that faster growing firms are more likely to have a female executive. Finally, the coefficients of the time dummies, with 1992 as base category, are significant in all the specifications at the $1 \%$ level up to the year 1999 and not significant for the years 2000 to 2003.

The results in Table VI stand mostly in line with the outcomes of the means difference tests reported earlier, and apart from the firm size measures also mainly with the ones showed in Table V. These observations can also be linked to the person-specific characteristics age and tenure of executives, which will be discussed in section 6 of this paper. As is shown later on, female executives are younger and have less work experience with their current company than their male colleagues, on average. Given that most executives are chosen from within the company, women are less likely to be chosen for top executive positions just because of their lower tenure, and their comparative advantage is more at newer companies and smaller companies, which also tend to have a higher growth potential.

As a robustness test, I estimate the probit and logit models with the lagged covariates instead of their levels. The results confirm the former findings. Again, all the statements in this section refer to partial correlations between the firm characteristics and the likelihood

${ }^{14}$ The table with the results from means-difference tests on the reduced sample can be found in the Appendix. 
Table VI Female executives and firm characteristics: Marginal effects of probit and logit estimations

\begin{tabular}{|c|c|c|c|c|c|c|}
\hline \multirow[t]{2}{*}{ 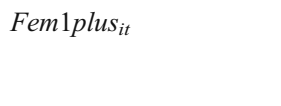 } & \multicolumn{2}{|l|}{ Model (1) } & \multicolumn{2}{|l|}{ Model (2) } & \multicolumn{2}{|l|}{ Model (3) } \\
\hline & probit & logit & probit & logit & probit & logit \\
\hline Sales $_{i t}$ & $\begin{array}{c}-0.12^{* *} \\
(0.04)\end{array}$ & $\begin{array}{c}-0.12 * * \\
(0.04)\end{array}$ & - & - & $\begin{array}{c}-0.11 * * \\
(0.04)\end{array}$ & $\begin{array}{c}-0.11 * * \\
(0.04)\end{array}$ \\
\hline Market value $_{i t}$ & - & - & $\begin{array}{r}-0.04 * \\
(0.02)\end{array}$ & $\begin{array}{r}-0.05^{*} \\
(0.03)\end{array}$ & - & - \\
\hline $\mathrm{EBIT}_{i t} /$ Total $_{\text {assets }} i t$ & $\begin{array}{r}-0.08 * * \\
(0.02)\end{array}$ & $\begin{array}{c}-0.07 * * \\
(0.02)\end{array}$ & - & - & $\begin{array}{r}-0.05^{*} \\
(0.02)\end{array}$ & $\begin{array}{r}-0.05^{*} \\
(0.02)\end{array}$ \\
\hline Earnings per share $_{i t}$ & - & - & $\begin{array}{l}-0.001 \\
(0.0028)\end{array}$ & $\begin{array}{r}-0.001 \\
(0.002)\end{array}$ & - & - \\
\hline $\begin{array}{l}\text { Long term debt }{ }_{i t} / \text { Total } \\
\text { assets }_{\text {it }}\end{array}$ & $\begin{array}{c}-0.10^{* *} \\
(0.02)\end{array}$ & $\begin{array}{c}-0.09 * * \\
(0.02)\end{array}$ & - & - & - & - \\
\hline $\begin{array}{l}\text { Current assets }_{i t} / \text { Current } \\
\text { liabilities }_{i t}\end{array}$ & - & - & $\begin{array}{l}0.01 * * \\
(0.001)\end{array}$ & $\begin{array}{l}0.01 * * \\
(0.001)\end{array}$ & $\begin{array}{l}0.01 * * \\
(0.001)\end{array}$ & $\begin{array}{l}0.01 * * \\
\quad(0.001)\end{array}$ \\
\hline Q-Ratio $_{i t}$ & $\begin{array}{l}0.01 * * \\
(0.002)\end{array}$ & $\begin{array}{l}0.01 * * \\
(0.002)\end{array}$ & - & - & $\begin{array}{l}0.01 * * \\
(0.002)\end{array}$ & $\begin{array}{l}0.01 * * \\
(0.002)\end{array}$ \\
\hline$\Delta$ Sales $_{i t}$ & - & - & $\begin{array}{r}0.002 * * \\
(0.001)\end{array}$ & $\begin{array}{r}0.002 * * \\
(0.001)\end{array}$ & - & - \\
\hline Wald $\chi^{2}$ & $817.71 * *$ & $793.90 * *$ & $788.94 * *$ & $763.16^{* *}$ & $808.13 * *$ & $777.98 * *$ \\
\hline $\mathrm{Nb}$. of observations & 14,417 & & & & & \\
\hline $\mathrm{Nb}$. of firms & 1,632 & & & & & \\
\hline
\end{tabular}

The table reports results from probit and logit estimations of the effects of firm characteristics on the likelihood that the company is managed by at least one woman. The dependent variable is the response probability $\mathrm{P}($ Femlplus $=1 \mid x)$, where Fem1plus is equal to one if there is at least one woman among the five top executives in a given year, and to zero otherwise. The Q-ratio is defined as total assets plus the difference between market value and book value of equity over total assets. Sales and Market values are in 100,000. All the ratios except the Q-ratio are in \%. The reported values are marginal effects at the mean level of the corresponding variables. Robust standard errors in brackets. Coefficients that are significantly different from zero at the $1 \%, 5 \%$, and $10 \%$ level are marked with $* *, *$, and $\left(^{*}\right)$ respectively. Time and industry dummies as well as constant included. The sample includes a total of 14,417 observations from 1,632 companies (sample 3). The time period covers the years 1992 to 2003. All data are reported in real 2003 dollars adjusted using the consumer price index. The datasource is the Compustat Executive Compensation database.

of female executives. Even though it might be interesting to know about the existence of causal relationships, e.g., Is a firm less leveraged because it has a female executive?, my analysis is clearly not able to answer this type of questions. Overall, I conclude that the set of variables included in the analysis can at least explain some of the variation in the dependent variable.

\section{Compensation issues}

It is a widely documented fact that the gender pay gap has narrowed over the past 25 years, but women still earn less than their male colleagues on average. ${ }^{15}$ To what extent does this hold for women in top executive positions? The purpose of this section is to document differences in compensation practices between male and female executives and how they have changed over the last years. In what follows, I look at the level and structure of

\footnotetext{
${ }^{15}$ See, e.g., Blau and Kahn [12]. 
compensation during the period 1992-2003 and check whether there are differences in compensation between men and women in executive positions. I then use earnings regressions to quantify the gender pay gap. In contrast to existing work, I do not only look at the mean of the distribution, but I use quantile regressions in order to characterize the gender pay gap over the entire distribution of total pay.

\subsection{Level and structure of compensation}

In a first step, I look at total pay and its components for male and female executives. Total pay is defined as the sum of the following four components: (a) salary is the dollar value of cash and non-cash salary; (b) bonus is the dollar value of cash and non-cash bonus; (c) options refers to the dollar value of options granted in the current period as valued using S\&P's Black Scholes methodology, and (d) other consists of the dollar value of annual compensation not categorized as salary or bonus. In order to have as broad a picture as possible, I use the main sample (sample 1), which includes all the observations that are non-missing for the four compensation components and has a total of 108,628 observations covering 26,047 executives and 2,598 firms.

As one can see from Table VII, average total pay amounts to 1,480,730 \$ for men and to $1,137,260$ \$ for women. The highest compensation of 56.4 Mio \$, which consisted of options only, was paid to the CEO of Apple Computer Inc. in 2000. The highest total

Table VII Total pay and its components for female and male executives

\begin{tabular}{lllllll}
\hline Variable & Mean & Std. dev. & Min & Max & Nb. of obs. & Nb. of executives \\
\hline All executives & & & & & & \\
Total pay & $1,467.00$ & $4,700.51$ & 0 & $564,326.50$ & 108,628 & 26,047 \\
Salary & 308.40 & 223.17 & 0 & $6,494.40$ & 108,628 & 26,047 \\
Bonus & 273.35 & 867.57 & 0 & $116,420.50$ & 108,628 & 26,047 \\
Options & 864.34 & $4,403.66$ & 0 & $564,326.50$ & 108,628 & 26,047 \\
Other & 20.93 & 197.67 & 0 & $31,651.63$ & 108,628 & 26,047 \\
Men & & & & & & \\
Total pay & $1,480.73$ & $4,771.26$ & 0 & $564,326.50$ & 104,286 & 24,693 \\
Salary & 310.29 & 224.20 & 0 & $6,494.40$ & 104,286 & 24,693 \\
Bonus & 277.03 & 881.95 & 0 & $116,420.50$ & 104,286 & 24,693 \\
Options & 872.13 & $4,472.16$ & 0 & $564,326.50$ & 104,286 & 24,693 \\
Other & 21.28 & 201.13 & 0 & $31,651.63$ & 104,286 & 24,693 \\
Women & & & & & & \\
Total pay & $1,137.26$ & $2,426.65$ & 0 & $63,591.52$ & 4,342 & 1,354 \\
Salary & 262.90 & 191.30 & 0 & $2,615.18$ & 4,342 & 1,354 \\
Bonus & 184.82 & 374.74 & 0 & 7,850 & 4,342 & 1,354 \\
Options & 677.11 & $2,180.21$ & 0 & $55,550.67$ & 4,342 & 1,354 \\
Other & 12.43 & 76.17 & 0 & $2,624.34$ & 4,342 & 1,354 \\
\hline
\end{tabular}

The table reports descriptive statistics of total compensation and its components. All data are reported in real 2003 thousands of dollars adjusted using the consumer price index. All executives include the top five highest paid executives in each firm in the database. The compensation components are defined as follows: salary =dollar value of cash and non-cash salary; bonus $=$ dollar value of cash and non-cash bonus; options= dollar value of options granted in the current period as valued using S\&P's Black Scholes methodology; other $=$ dollar value of annual compensation not categorized as salary or bonus; pay_tot=the sum of salary, bonus, options and other. The time period covers the years from 1992 to 2003. All data are reported in real 2003 thousands of dollars adjusted using the consumer price index. The datasource is the Compustat Executive Compensation database. 
compensation paid to a female executive amounts to 63.6 Mio., and it was paid in 1998 to the CEO of Warnaco Group Inc., a consumer product manufacturer based in the state of New York. Two-sided means difference tests with unequal variance confirm that total pay as well as all its components are significantly higher (at the 1\% level) for men than for women in the sample. On average, female executives receive $23.2 \%$ less in total compensation than their male colleagues.

When looking at the yearly compensation figures over the time period considered, I find that total compensation of male executives is always higher than total pay of women in executive positions during the time period considered, and the difference is always significant except in 1992. Also, total compensation, which is expressed in 2003 \$, increases until 2000 and starts to fall from then on, and this holds for both men and women. Finally, the absolute difference in total pay between men and women increases as long as total pay is rising, with a peak in 2000, and starts to shrink with decreasing total compensation. This may suggest that the gender pay gap is not constant over time and that it depends on the absolute level of compensation.

Before further investigating the gender pay gap in the next subsection, I take a look at the structure of compensation. This is motivated by the following two facts. First, compensation contracts are typically negotiated between executives and companies and reflect, therefore, the executives' preferences. Second, the structure of compensation mirrors the strength of incentives for executives, and this may well be related to the gender composition of the top management. As Kanter [23] argues, diverse top management teams cooperate less, and additional mechanisms are necessary in order to induce cooperation. Incentive pay can be such a cooperation mechanism. ${ }^{16}$

To capture the structure of compensation, I consider the variable pay share, which is defined as total pay minus salary over total pay, and the share of options, which is defined as the value of options over total pay. A higher variable share or a higher option share means that executives face stronger incentives. ${ }^{17}$ Two-sided means-difference tests reveal that the variable share does not systematically differ between men and women, but that women obtain a significantly higher option share over the whole period. Note that the latter result may be driven by the fact that in recent years it has become more common for women to be in executive positions and for stock options to be used for compensation. To confirm this, I run a simple OLS regression where I explain the option share optsh by a constant, the dummy variable female, and mktval as proxy for firm size. The coefficient of female is significant at the $1 \%$ level. Once I include time dummies, however, there is no significant gender effect anymore. I conclude that the structure of compensation does not significantly differ between men and women in executive positions. ${ }^{18}$ Apart from gender considerations, I also find that the variable share in compensation as well as the option share in particular for both men and women have increased over the years until 2000 or 2001, and started to decrease from then on.

\footnotetext{
${ }^{16}$ Adams and Ferreira [1] provide empirical evidence for US firms that more diverse board provide stronger incentives for their directors.

${ }^{17}$ See Murphy [28] for an overview of compensation practices.

${ }^{18}$ I also computed the pay-performance sensitivity according to Jensen and Murphy [22], where the change in compensation from year $(t-1)$ to $t$ is regressed on the change in shareholder wealth over the same period. To see a potential gender effect, I included an interaction term equal to the multiplication of the change in shareholder wealth by the dummy variable fem. I found no systematic difference between women and men, i.e., the significance of the lower pay-performance sensitivity for female executives disappeared once I included firm size as control variable [5].
} 


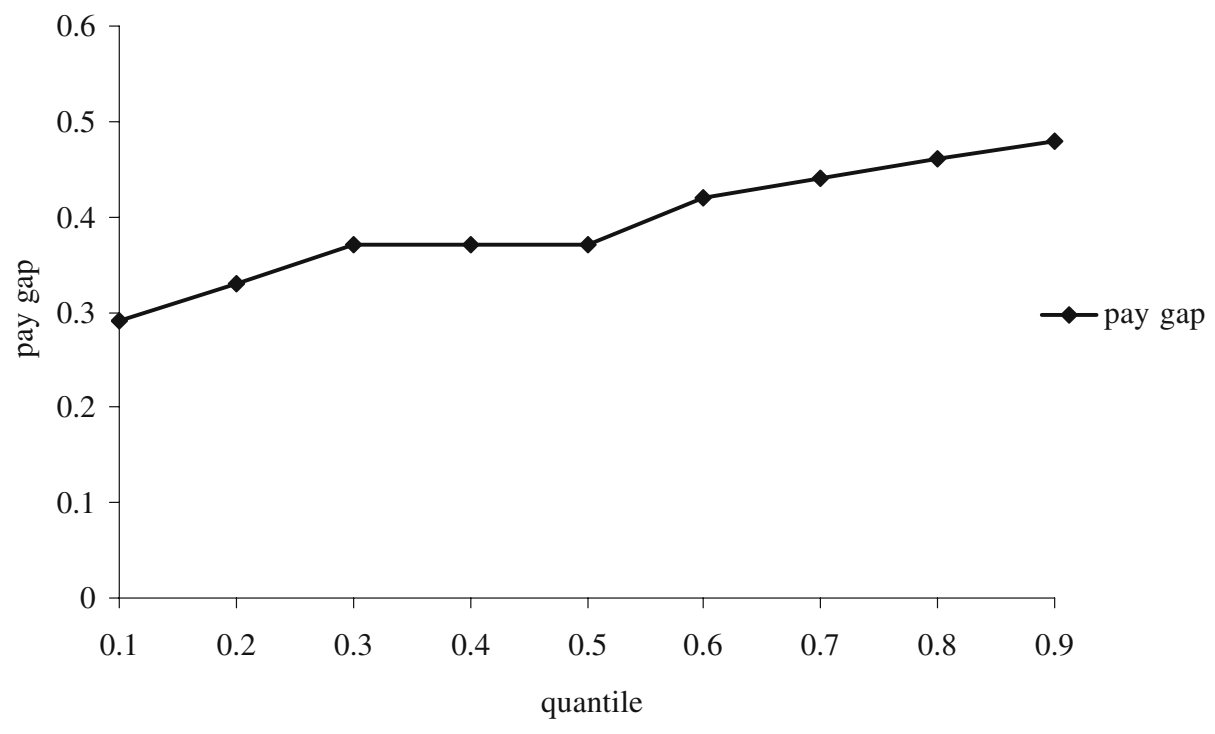

Figure 2 The figure reports the raw pay gap by quantile. The raw wage gap is defined as the log of total pay of men minus the log of total pay of women. Total pay is the sum of salary, bonus, options, and other. The sample includes a total of 108,628 observations from 26,047 executives and 2,598 companies (sample 1). The time period covers the years from 1992 to 2003. All data are reported in real 2003 thousands of dollars adjusted using the consumer price index. The datasource is the Compustat Executive Compensation database.

\subsection{Pay distribution and gender pay gap}

To further investigate the pay distributions and the gender pay gap in particular, I plot the raw distribution of the log of total pay for male and female executives. I first carry out a Kolmogorov-Smirnov test and find strong evidence against the equality of the two distribution functions. ${ }^{19}$ The distribution of men's total pay is slightly shifted to the right compared to the women's distribution. This location shift reflects the positive mean (and median) gender gap as mentioned earlier.

In addition to the location, the pay distributions of male and female executives also differ somewhat with respect to scale and shape, implying that the gender pay gap is not constant over the wage distribution. To see this, I compute a variable for the pay gap, which is defined as the difference of the log male and log female average total pay. Figure 2 reports the pay gap by quantile.

As can be seen from Figure 2, there is a tendency for the gender pay gap to increase towards the top of the unconditional wage distribution. Note that this observation may be due to the existence of a glass ceiling, i.e., women, otherwise identical to men, can only advance so far up the pay ladder. But it might also be the consequence of other mechanisms. For instance, it is possible that women are less willing to take a job as a top executive compared to men, given that preferences as well as other personal conditions may differ between women and men. Also, I have not yet taken into account any human capital variable as well as firm-specific characteristics.

\footnotetext{
${ }^{19}$ The $P$ value for the combined K-S test is 0.00 .
} 


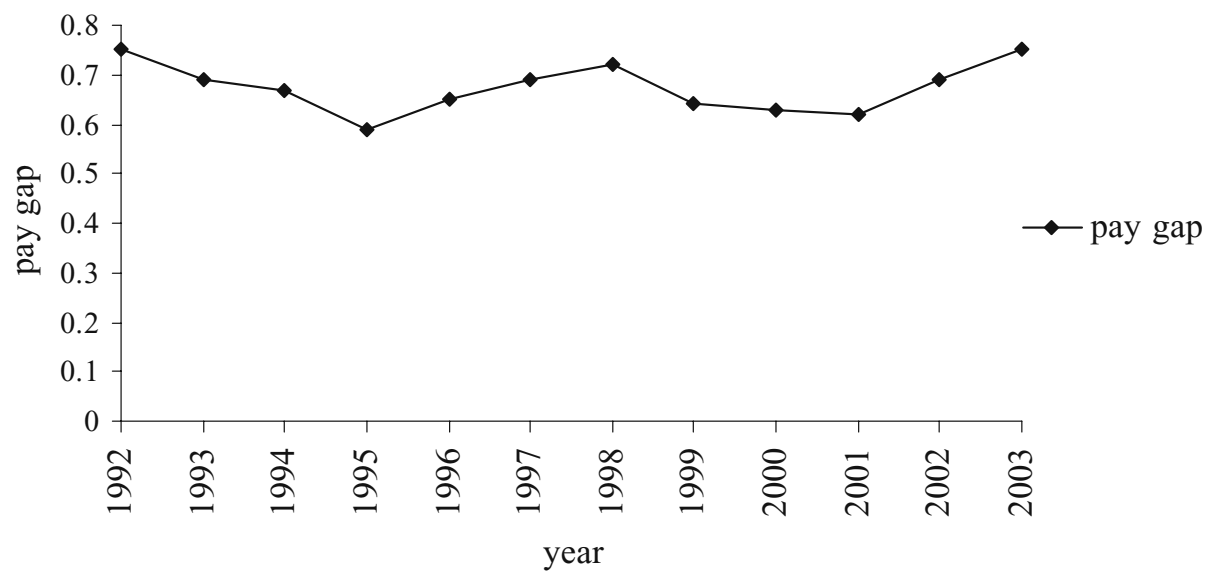

Figure 3 The figure reports the raw pay gap over time, where the pay gap is defined as the difference of the $\log$ male and log female average total pay. Total pay is the sum of salary, bonus, options, and other. The sample includes a total of 108,628 observations from 26,047 executives and 2,598 companies (sample 1). The time period covers the years from 1992 to 2003. All data are reported in real 2003 thousands of dollars adjusted using the consumer price index. The datasource is the Compustat Executive Compensation database.

Before exploring this issue, let me look at the raw pay gap over time. As can be seen from Figure 3, no clear pattern emerges except that the unconditional wage gap varies over time. In particular, the values for 1992 and 2003 are very close to each other, implying that the raw pay gap has not steadily decreased over time.

So far, I have looked at the raw pay gap only. Given that men and women may differ in terms of pay-relevant characteristics, I need to control for person- and firm-specific attributes in order to validate my preliminary findings. For this purpose, I follow Bertand and Hallock [10] and use a standard earnings differential model based on the human capital earnings function developed by Mincer [25]. The model is given by Equation (7).

$$
\begin{aligned}
\log \left(\text { TotalPay }_{k t}\right)= & \beta_{0}+\beta_{1} \text { Female }_{k}+\beta_{2} \log \left(\text { Marketvalue }_{i t}\right)+\beta_{3}\left(\text { EBIT }_{i t} / \text { TotalAssets }_{i t}\right) \\
& +\beta_{4} \text { Age }_{k t}+\beta_{5} \text { Age }_{k t}^{2}+\beta_{6} \text { Tenure }_{k t}+\beta_{7} \text { Tenure }_{k t}^{2}+\beta_{8} \text { CEO }_{k t} \\
& +\sum_{j} \gamma_{j} I_{j}+\sum_{t} \delta_{t} D_{t}+\varepsilon_{k t} \\
i= & 1, \ldots, N \quad k=1, \ldots, K \quad j=1, \ldots, J \quad t=1, \ldots, T
\end{aligned}
$$

The dependent variable is the log of total pay for executive $k$ in year $t$. As explanatory variables I include a dummy variable Female that is equal to one if the executive is a woman and zero otherwise. Accordingly, the coefficient $\beta_{1}$ captures the gender compensation gap. Given that larger and more profitable firms are expected to pay higher compensation [8], I use the log of the market value as a proxy for firm size and the earnings before interests and taxes (EBIT) over total assets as a performance measure. Furthermore, I utilize age and tenure of the executives as human capital variables, and I also include the square of both variables to allow for non-linear effects. In addition, I take into account whether the executive holds the chief executive position, i.e., I build the dummy variable $C E O$ that is equal to one if the executive is the chief executive officer in a given year, and zero else. Finally, I control for time and industry effects, with the chemical (and other material) manufacturing industry as the benchmark case. The error term $\varepsilon$ is assumed to be normally distributed with mean zero and variance $\sigma^{2}$. 
Model (7) is estimated with pooled OLS, and results are reported for different specifications in order to isolate the effects of firm-, industry- and person-specific attributes. Given that the Compustat Executive Database does not report age and tenure consistently for all executives, the sample size drops to a total of 12,771 observations covering 1,111 firms and 1,802 executives (sample 4). The descriptive statistics of the variables used in the earnings regressions are given in the most rightward columns of Table VIII. Besides the CEO position, male and female executives in the sample differ also with respect to their age and to the number of years they have been working for this company (tenure). Compared to men, women in executive positions are 4.5 years younger and have over 3 years less work experience for a given company, on average. It is worth

Table VIII Gender effect in compensation: pooled OLS regressions

\begin{tabular}{|c|c|c|c|c|c|c|c|c|}
\hline \multirow[t]{2}{*}{ Log(Total pay) } & \multirow[t]{2}{*}{ (1) } & \multirow[t]{2}{*}{ (2) } & \multirow[t]{2}{*}{ (3) } & \multirow[t]{2}{*}{ (4) } & \multicolumn{4}{|c|}{ Mean (Standard deviation) } \\
\hline & & & & & All & Men & Women & $\begin{array}{l}p- \\
\text { value }\end{array}$ \\
\hline Female $_{k t}$ & $\begin{array}{c}-0.22 * * \\
(0.07)\end{array}$ & $\begin{array}{c}-0.29 * * \\
(0.06)\end{array}$ & $\begin{array}{c}-0.23 * * \\
(0.06)\end{array}$ & $\begin{array}{c}-0.13 * * \\
(0.05)\end{array}$ & 0.02 & 0 & 1 & - \\
\hline $\begin{array}{l}\log \\
\left(\text { MarketValue }_{i t}\right)\end{array}$ & - & $\begin{array}{r}0.42 * * \\
(0.01)\end{array}$ & $\begin{array}{r}0.41 * * \\
(0.01)\end{array}$ & $\begin{array}{r}0.40 * * \\
(0.01)\end{array}$ & $\begin{array}{l}7.19 \\
(1.66)\end{array}$ & $\begin{array}{l}7.19 \\
(0.20)\end{array}$ & $\begin{array}{l}7.49 \\
(0.10)\end{array}$ & 0.22 \\
\hline $\begin{array}{l}\mathrm{EBIT}_{i t} / \text { Total } \\
\text { assets }_{i t}\end{array}$ & - & $\begin{array}{c}-0.57 * * \\
(0.07)\end{array}$ & $\begin{array}{r}-0.57 * * \\
(0.001)\end{array}$ & $\begin{array}{c}-0.53 * * \\
(0.07)\end{array}$ & $\begin{array}{l}13.43 \\
(11.95)\end{array}$ & $\begin{array}{l}13.42 \\
(11.96)\end{array}$ & $\begin{array}{l}13.91 \\
(11.54)\end{array}$ & 0.49 \\
\hline $\mathrm{Age}_{k t}$ & - & - & $\begin{array}{r}0.04 * * \\
(0.01)\end{array}$ & $\begin{array}{l}-0.01 \\
(0.01)\end{array}$ & $\begin{array}{l}56.25 \\
(7.82)\end{array}$ & $\begin{array}{l}56.35 \\
(7.81)\end{array}$ & $\begin{array}{l}51.80 \\
(6.86)\end{array}$ & 0.00 \\
\hline $\operatorname{Age}_{k t}^{2}$ & - & - & $\begin{array}{c}-0.0002 * \\
(0.00)\end{array}$ & $\begin{array}{l}0.0002 * * \\
(0.00)\end{array}$ & & & & \\
\hline Tenure $_{k t}$ & - & - & $\begin{array}{l}0.01 * * \\
(0.003)\end{array}$ & $\begin{array}{l}0.02 * * \\
(0.003)\end{array}$ & $\begin{array}{l}13.85 \\
(10.19)\end{array}$ & $\begin{array}{l}13.92 \\
(10.20)\end{array}$ & $\begin{array}{l}10.59 \\
(10.04)\end{array}$ & 0.00 \\
\hline Tenure $_{k t}^{2}$ & - & - & $\begin{array}{c}-0.0003^{* *} \\
(0.00)\end{array}$ & $\begin{array}{c}-0.001^{* *} \\
(0.00)\end{array}$ & & & & \\
\hline $\mathrm{CEO}_{k t}$ & - & - & - & $\begin{array}{r}0.54 * * \\
(0.02)\end{array}$ & 0.62 & 0.63 & 0.40 & - \\
\hline constant & $\begin{array}{r}6.13 * * \\
(0.05)\end{array}$ & $\begin{array}{r}3.61 * * \\
(0.06)\end{array}$ & $\begin{array}{r}1.95 * * \\
(0.29)\end{array}$ & $\begin{array}{r}3.18 * * \\
(0.29)\end{array}$ & & & & \\
\hline $\begin{array}{l}\text { Industry } \\
\text { dummies }\end{array}$ & no & yes & yes & yes & & & & \\
\hline $\mathrm{F}$ & $153.20 * *$ & $358.74 * *$ & $335.207^{*}$ & $376.33 * *$ & & & & \\
\hline $\mathrm{R}^{2}$ & 0.10 & 0.40 & 0.41 & 0.45 & & & & \\
\hline $\begin{array}{l}\mathrm{Nb} \text {. of } \\
\text { observations }\end{array}$ & 12,771 & 12,771 & 12,771 & 12,771 & 12,771 & 12,506 & 265 & \\
\hline $\mathrm{Nb}$. of firms & 1,111 & 1,111 & 1,111 & 1,111 & & & & \\
\hline $\begin{array}{l}\mathrm{Nb} \text {. of } \\
\text { executives }\end{array}$ & 1,802 & 1,802 & 1,802 & 1,802 & 1,802 & 1,740 & 62 & \\
\hline
\end{tabular}

The table reports estimates from pooled OLS regressions (left part of table) as well as descriptive statistics of the regression variables (right part of table). The dependent variable is the log(Total pay), which is the sum of salary, bonus, other and options. Robust standard errors in brackets. Coefficients that are significantly different from zero at the $1 \%, 5 \%$, and $10 \%$ level are marked with **, $*$, and $\left(^{*}\right)$ respectively. Time dummies included. The $P$ value refers to the difference in sample means between males and female executives (twosided means difference test with unequal variance). The time period covers the years from 1992 to 2003 . All data are reported in real 2003 thousands of dollars adjusted using the consumer price index. The datasource is the Compustat Executive Compensation database. 
mentioning that, on average, women earn less than men (the mean of total pay is 2,726.66 for men and 2,259.73 for women, where the difference is significant at the $1 \%$ level). But it is also the case that women reach top executive positions at a younger age and after a shorter tenure, compared to their male colleagues. The latter observation could even be interpreted as discrimination in favor of women.

The estimation results are reported in the left part of Table VIII. The coefficient of Female in column (1) reports the unconditional gender earnings gap, which is $22 \%$ in this sample. When controlling for firm size, profitability and industry affiliation, the gender wage gap increases to $29 \%$. The gender gap is however only $23 \%$ when controlling for age and tenure of executives (column 3), and it is further reduced to $13 \%$ when I include the CEO dummy as shown in column (4) of Table VIII. Note that Bertrand and Hallock [10], who carry out a similar analysis for the period 1992-1997, find an unconditional gender earnings gap of $61 \%$. In their final specification, where they include other occupational characteristics beside the CEO rank and also control for age, tenure firm size and performance, they find that the gender compensation gap falls below $5 \%$.

As expected, firm size has a positive effect on total compensation of executives. In contrast, the coefficient for the performance measure "profitability" is negative and statistically significant in all the specifications. Bertand and Hallock [10] do not find a significant effect of firm performance as measured by the return on equity.

I find a positive and significant effect of age on compensation, but it disappears when I include the CEO dummy variable. Tenure has a positive, but decreasing effect on total pay as well. Even though it is statistically significant at the $1 \%$ level, the effect is rather weak from an economic point of view, meaning that an additional year of employment with a firm increases total compensation by $1 \%$ or $2 \%$ only. ${ }^{20}$ Finally, the last specification in column (4) shows that being a CEO is indeed attractive from a financial point of view, given that executives in the CEO positions earn $54 \%$ more on average. Note that these results provide empirical evidence for hypothesis 3, as outlined in section 2 of the paper.

To check the robustness of my results, I repeat the pooled OLS estimations while replacing the profitability EBIT over total assets measure by the return on equity. The results are very similar to the ones reported in Table VIII, also with a negative effect of firm performance on compensation. $^{21}$

To see whether the gender pay gap has changed over the years, I run yearly regressions of model (7). The coefficient of Female is not significant in all the years, and from the year 1999 on it is significant in one year and at the 5\% level only. This observation may provide some evidence for a slightly narrowing gender pay gap over time. But note that a longer time series would be needed to make a definite statement about that. Bertrand and Hallock [10], who also run yearly regressions for 1992 to 1997, find a significant coefficient of Female up to 1996. Polachek [29], who investigates wage profiles over a wide set of professions, industries and years, finds a narrowing gender wage over time, with a deceleration in the mid $1990 \mathrm{~s}^{22}$

Finally, let me come back to my former observation that the gender pay gap may increase towards the top of the wage distribution, as illustrated in Figure 2. For this purpose I estimate model (7) with quantile regressions, using bootstrapped standard errors. The

\footnotetext{
${ }^{20}$ I also tried to interact Female with Age and Tenure, respectively, in order see whether interaction effects play an additional role. However, it did not lead to any significant result.

21 The results from the robustness checks are available from the author upon request.

${ }^{22} \mathrm{He}$ explains the diminishing gender wage gap by the fact that the lifetime work expectations have become more similar for women and men over the years. The deceleration in the mid 1990s, on the other hand, may be due to a slower trend of convergence in male and female labor force participation.
} 


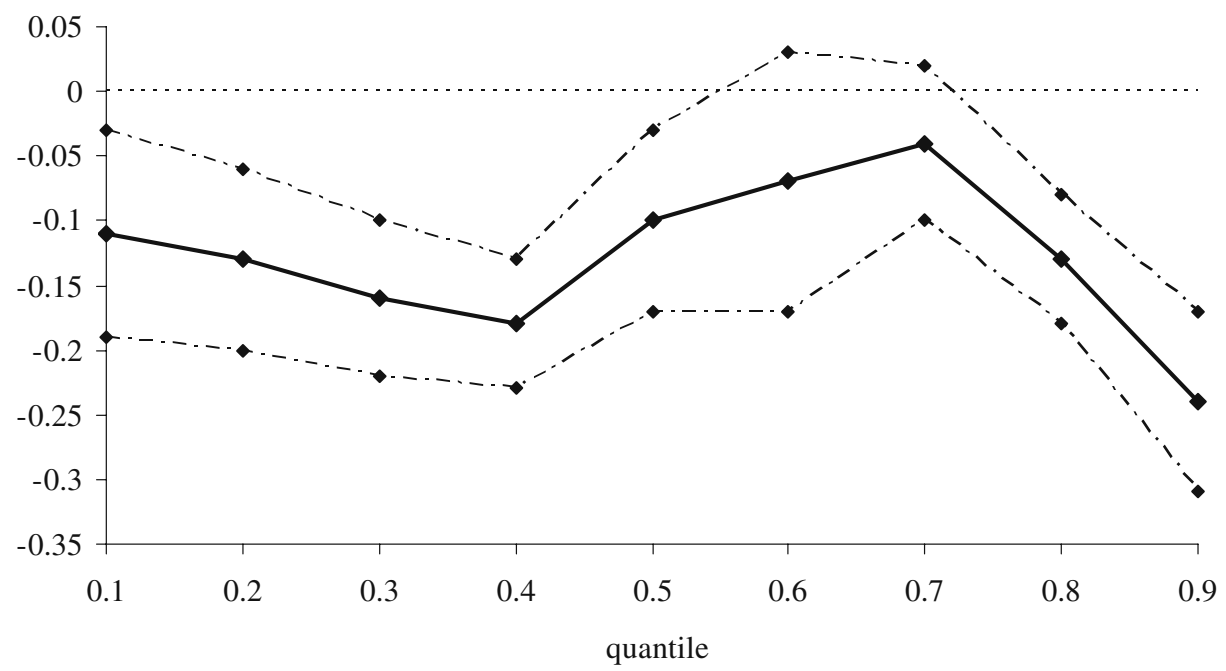

$\neg$ pay gap coefficient

Figure 4 The figure reports the distribution of the pay gap coefficient from quantile regressions with bootstrapped standard errors. The dependent variable log (total pay) is regressed on a dummy variable female, which is equal to one if the executive is a woman and zero otherwise, and on firm- and other personspecific variables such as size and profitability of the firm, age and age squared of the executive, tenure squared of the executive and a CEO dummy. The sample includes a total of 12'771 observations from 1'802 executives and 1'111 companies (sample 4). The time period covers the years from 1992 to 2003. All data are reported in real 2003 thousands of dollars adjusted using the consumer price index. The datasource is the Compustat Executive.

main advantage of the quantile regression model is that it allows me to characterize the entire conditional distribution of the dependent variable given a set of regressors. In contrast to OLS (that gives information about the effects of the regressors at the conditional mean of the dependent variable only), quantile regressions provide parameter estimates at different quantiles, and, therefore, generate information on the variations in the effect of independent variables on the dependent variable at different quantiles. Also, the quantile regression objective function is a weighted sum of absolute deviations, which gives a robust measure of location so that the estimated coefficient vector is not sensitive to outlier observations on the dependent variable. The inclusion of person- and firm-specific controls assures again that the results are not driven by different characteristics of men and women. ${ }^{23}$

Instead of reporting the complete results, I focus on the coefficient of the dummy variable female, which quantifies the gender pay gap. ${ }^{24}$ As can be seen from Figure 4, the absolute value of the gender compensation gap is fairly constant at about $13 \%$ to $18 \%$ over the first four deciles, with no significant coefficient for the first quantile. From the 5 th to the 7 th decile, the (absolute value of the) compensation gap between men and women becomes smaller and is not even significantly different from zero, before it starts to increase up to $24 \%$ towards to upper end of the distribution.

\footnotetext{
${ }^{23}$ See, e.g., Buchinsky [13] for a practical guideline for quantile regression models. Papers that look at the gender gap across wage distributions include, e.g., Albrecht et al. [2], Dolado and Llorens [17] and Arulampalam et al. [4].

${ }^{24}$ The detailed results of the quantile regressions can be found in Table IX of the Appendix.
} 
These results confirm that the gender pay gap is not constant along the pay distribution. In particular, the gender pay gap is largest towards the right end of the distribution. This means that the pay difference between men and women is highest when total pay is very high. Again, I cannot know whether this observation is due to the existence of a glass ceiling, ${ }^{25}$ i.e., that women otherwise identical to men can only climb up the pay ladder up to a certain extent, or whether it is also driven by other factors which are outside the control of corporations. For instance, marital status, children as well as human capital variables like education play a major role in the gender pay gap. In case a woman has several children, it is also important to know how widely apart the births were spaced and whether at some stage she dropped out of the labor force (see, e.g., [29]). The role of the husband or the partner and his particular job may also play a very important role. The cover story of the October 14, 2002 issue of Fortune magazine "The New Trophy Huband", for instance, describes the situation of a dozen successful women who attribute their career accomplishments to a husband staying at home and managing the family. As the Betsy Morris, the author of this article, argues, "... Behind a great woman at work there is often a great man at home. He is the new trophy husband". Accordingly, if there were enough trophy husbands, it would probably be easier for women to move up to the highest executive positions. Finally, it is also possible that women are less willing to be among the top executives, in comparison to men. In this case, it would be misleading to talk about a glass-ceiling. In order to further investigate this issue, I would clearly need more information on the preferences of executives. Given that my data are limited to person-specific factors like gender, age and tenure, I am not able to disentangle the different mechanisms that may be at work. Note that the coefficients of the other explanatory variables included in the analysis do not vary very much over the distribution.

\section{Conclusions}

This study attempts to give a recent overview of the status of women in top executive positions of large US corporations. It describes the distribution of women in top executive positions across industries and over time. Furthermore, it characterizes differences between corporations led by men versus women, and it finally addresses the issue of pay differences between men and women in executive positions.

The share of female top executives steadily increased over the years. Whereas less than two out of 100 top executives were women in 1992, there were six women for every hundred top executives, on average in the year 2003. Female CEOs, however, were and still are very much a rarity in top US corporations. Furthermore, I find that firms with a woman in the CEO positions are more likely to have one or more other women among their top executives in comparison to companies with male CEOs. Finally, female executives tend to work for smaller and less profitable firms. They also seem to be at the head of less risky and faster growing companies.

The analysis of compensation practices reveals some gender differences in executive positions. Women otherwise identical to men earn about $14 \%$ less than their male colleagues. Also, the gender pay gap is not constant along the pay distribution, and this difference is largest towards the right end of the distribution. While this observation may be due to the existence of a glass ceiling, it can also be driven by other factors which I do not explicitly control for in the analysis.

\footnotetext{
${ }^{25}$ If glass ceilings existed, they would allow people to see the world above them. Because glass is transparent, those working under such a ceiling might not, at first, even notice that there was a barrier separating them from higher levels. Yet if they tried to pass through it, they would quickly learn that the ceiling prevented any such rise. This analogy is often used to describe the situation of women and minorities, who are alledgedly kept from achieving any but token positions at the highest echelons of corporate America. For further information see also http://home.earthlink.net/ rdmadden/webdocs/Shattering_the_Glass_Ceili.html.
} 
This paper provides some recent insights on the status of women in top corporate America and provides further evidence on existing inequalities between men and women. Further work based on different and richer data is needed to obtain a more complete understanding of the mechanisms behind the distribution of female executives in corporations. It would be interesting, for instance, to look not only at firms listed on stock markets, but also at smaller firms, where women are thought to play a more important role. It may also be fruitful to consider more information about the human capital of executives, their personals situation such as their marital status, the number of their children and the role of their husband or partner in managing household and family life. This type of information may be useful to better understand the differences in the distribution of male and female executives. Besides following the trend over time, one should provide comparisons of the role of women in top executive positions across countries and continents in order to understand the effects of factors such as legislations, structure of labor markets, corporate cultures and social norms.

Finally, it remains an open question whether women more often choose to stay outside the executive world of large corporations. After all, a top executive position usually means long work hours and a lot of stress. Depending on a person's preferences, which are likely to be gender-specific too, power, status and big cash may not always be perfect enough substitutes for such sacrifices.

Acknowledgments I would like to thank Mike Gerfin, Sabina Littmann-Wernli, Anthony Mowers, Heather Murray, Kurt Schmidheiny, Jacques Silber and three anonymous referees for helpful suggestions and comments. Remaining errors are mine.

\section{Appendix}

Table IX Gender effect in compensation: pooled OLS and quantile regressions

\begin{tabular}{llllll}
\hline $\log ($ Total pay $)$ & OLS & 1st decile & 2nd decile & 3rd decile & 4th decile \\
\hline Female & $-0.13^{* *}(0.05)$ & $-0.11^{*}(0.08)$ & $-0.13^{*}(0.07)$ & $-0.16^{* *}(0.06)$ & $-0.18^{* *}(0.05)$ \\
$\log ($ mktval $)$ & $0.40^{* *}(0.01)$ & $0.34^{* *}(0.01)$ & $0.36^{* *}(0.01)$ & $0.38^{* *}(0.01)$ & $0.40^{* *}(0.01)$ \\
Profit & $-0.57^{* *}(0.07)$ & $-0.45^{* *}(0.11)$ & $-0.46^{* *}(0.11)$ & $-0.49^{* *}(0.10)$ & $-0.56^{* *}(0.10)$ \\
Age & $-0.02(0.01)$ & $\left.0.04)^{*}\right)(0.02)$ & $0.01(0.02)$ & $-0.01(0.01)$ & $-0.02\left(^{*}\right)(0.01)$ \\
Age $^{2}$ & $0.0002^{* *}(0.00)$ & $-0.0002(0.00)$ & $0.00(0.00)$ & $0.0002^{* *}(0.00)$ & $0.0003^{* *}(0.00)$ \\
Tenure & $0.02^{* *}(0.003)$ & $0.02^{* *}(0.003)$ & $0.01^{* *}(0.003)$ & $0.02^{* *}(0.003)$ & $0.02^{* *}(0.003)$ \\
Tenure & $-0.0005^{* *}(0.00)$ & $-0.0004^{* *}(0.00)$ & $-0.0003^{* *}(0.00)$ & $-0.0004^{* *}(0.00)$ & $-0.0005^{* *}(0.00)$ \\
CEO & $0.54^{* *}(0.02)$ & $0.56^{* *}(0.03)$ & $0.56^{* *}(0.02)$ & $0.55^{* *}(0.02)$ & $0.55^{* *}(0.02)$ \\
Constant & $3.27^{* *}(0.29)$ & $\left.1.177^{*}\right)(0.62)$ & $2.05^{* *}(0.43)$ & $2.85^{* *}(0.32)$ & $3.06^{* *}(0.32)$ \\
$F$ & $376.33^{* *}$ & & & & 0.31 \\
(Pseudo) $R^{2}$ & 0.45 & 0.23 & 0.28 & & 0.33 \\
Nb. of obs. & 12,771 & & & & \\
Nb. of firms & 1,111 & & & & \\
Nb. of executives & 1,802 & & & & \\
\hline
\end{tabular}




\begin{tabular}{|c|c|c|c|c|c|}
\hline $\log$ (Total pay) & 5th decile & 6th decile & 7th decile & 8th decile & 9th decile \\
\hline Female & $-0.10(0.07)$ & $-0.07(0.10)$ & $-0.04(0.06)$ & $-0.13 * *(0.05)$ & $-0.24 * *(0.07)$ \\
\hline $\log (m k t v a l)$ & $0.41 * *(0.01)$ & $0.41 * *(0.01)$ & $0.43 * *(0.01)$ & $0.44 * *(0.01)$ & $0.47 * *(0.01)$ \\
\hline Profit & $-0.53 * *(0.10)$ & $-0.57 * *(0.10)$ & $-0.55 * *(0.10)$ & $-0.51 * *(0.10)$ & $-0.71 * *(0.10)$ \\
\hline Age & $-0.02(*)(0.01)$ & $-0.03 *(0.02)$ & $-0.05 * *(0.01)$ & $-0.06^{* *}(0.01)$ & $-0.07 *(0.03)$ \\
\hline $\mathrm{Age}^{2}$ & $0.0003^{* *}(0.00)$ & $0.0004 * *(0.00)$ & $0.001 * *(0.00)$ & $0.001 * *(0.00)$ & $0.001 * *(0.00)$ \\
\hline Tenure & $0.02 * *(0.003)$ & $0.02 * *(0.003)$ & $0.02 * *(0.002)$ & $0.01 * *(0.003)$ & $0.002(0.003)$ \\
\hline Tenure $^{2}$ & $-0.0004 * *(0.00)$ & $-0.0004 * *(0.00)$ & $-0.0004 * *(0.00)$ & $-0.0004 * *(0.00)$ & $-0.0002\left(^{*}\right)(0.00)$ \\
\hline $\mathrm{CEO}$ & $0.55 * *(0.02)$ & $0.56 * *(0.02)$ & $0.56^{* *}(0.02)$ & $0.54 * *(0.03)$ & $0.48 * *(0.02)$ \\
\hline $\begin{array}{l}\text { Constant } \\
F\end{array}$ & $3.21 * *(0.29)$ & $3.85 * *(0.32)$ & $4.40(0.52)$ & $4.86 * *(0.37)$ & $5.52 * *(0.60)$ \\
\hline $\begin{array}{l}\text { (Pseudo) } R^{2} \\
\mathrm{Nb} \text {. of obs. } \\
\mathrm{Nb} \text {. of firms } \\
\mathrm{Nb} \text {. of executives }\end{array}$ & 0.34 & 0.35 & 0.36 & 0.35 & 0.34 \\
\hline
\end{tabular}

The table reports estimates from pooled OLS and quantile regressions. The dependent variable is the log (total pay), which is the sum of salary, bonus, other and options. The explanatory variables are as follows: female $=1$ if executive is a woman, and zero otherwise; $\log (m k t v a l)$, where mktval is the market value of equity; profit ta $=\mathrm{EBIT} /$ total assets; age=age of executive; tenure=number of years working for the company; $C E O=1$ if the executives holds the CEO position, and zero otherwise. Robust (OLS) and bootstrapped standard errors (for quantile regressions) in brackets. Coefficients that are significantly different from zero at the $1 \%, 5 \%$, and $10 \%$ level are marked with $* *, *$, and $\left(^{*}\right)$ respectively. Time dummies included. The time period covers the years 1992-2003. All data are reported in real 2003 thousands of dollars adjusted using the consumer price index. The datasource is the Compustat Executive Compensation data.

\section{References}

1. Adams, R.B., Ferreira, D.: Gender Diversity in the Boardroom, Finance Working Paper No. 57/2004, Stockholm School of Economics and ECGI (2004)

2. Albrecht, J., Bjorklund, A., Vroman, S.: Is there a glass ceiling in Sweden? J. Lab. Econ. 21, 145-177 (2003)

3. Altmann, E.I., Narayanan, P.: An international survey of business failure classification models. Financ. Mark. Inst. Instrum. 6, 1-57 (1997)

4. Arulampalam, W., Booth, A.L., Bryan, M.L.: Is there a glass ceiling over Europe? Exploring the gender pay gap across wage distributions. IZA Discussion Paper Series, No. 1373 (2004)

5. Baker, G.P., Hall, B.J.: CEO incentives and firm size. NBER Working Paper No. 6868 (1998)

6. Baldwin, M.L., Butler, R.J., Johnson, W.G.: A hierarchical theory of occupational segregation and wage discrimination. Econ. Inq. 39, 94-110 (2001)

7. Barber, B.M., Odean, T.: Boys will be boys: Gender, overconfidence, and common stock investment. Q. J. Econ. 116, 261-292 (2001)

8. Bartlett, R.L., Miller, T.I.: Executive compensation: Female executives and networking. Am. Econ. Rev. 75, 266-270 (1985)

9. Becker, G.: The Economics of Discrimination. University of Chicago Press, Chicago (1971)

10. Bertrand, M., Hallock, K.: The gender gap in top corporate jobs. Ind. Lab. Relat. Rev. 55, 3-21 (2001)

11. Bevan, A.A., Danbolt, J.: Capital structure and its determinants in the UK - a decomposition analysis. Appl. Financ. Econ. 12, 159-170 (2002)

12. Blau, F., Kahn, L.M.: Gender differences in pay. J. Econ. Perspect. 14, 75-99 (2000)

13. Buchinsky, M.: Recent advances in quantile regression models. A practical guideline for empirical research. J. Hum. Resour. 33, 88-126 (1998)

14. Burke, R.J.: Women on corporate boards of directors: a needed resource. J. Bus. Ethics 16, 909-915 (1997)

15. Carter, N. M., Brush, C. G., Gatewood, E. J., Greene, P. Hart, M. M.: Financing High-Growth Enterprise: Is Gender an Issue? In: Critical Junctures in Women's Economic Lives: A Collection of Symposium Papers, pp. 45-51. Minneapolis, The Center for Economic Progress (2002)

16. Davies-Netzley, S.A.: Women above the glass ceiling: perceptions on corporate mobility and strategies for success. Gend. Soc. 12, 339-355 (1998) 
17. Dolado, J.J., Llorens, V.: Gender wage gaps by education in Spain: glass floors vs. glass ceilings, CEPR Discussion Paper, No. 4203 (2004)

18. Ellis, K.M., Keys, P.Y.: Stock Returns and the Promotion of Workforce Diversity, Working Paper, University of Delaware (2003)

19. Estes, R., Hosseini, J.: The gender gap on Wall Street: an empirical analysis of confidence in investment decision making. J. Psychol. 122, 577-590 (1988)

20. Hallock, K.F.: The Gender Pay and Employment Gaps for Top Managers in U.S. Nonprofits. Working Paper University of Illinois (2002)

21. Hunter, F., Reid, T.: The power game: do women make better bosses? Sunday Telegraph London, November 3, 1996 (1996)

22. Jensen, M.C., Murphy, K.J.: Performance pay and top-management incentives. J. Polit. Econ. 90, 225-264 (1990)

23. Kanter, R.M.: Men and Women in Corporations. Basic Books, New York (1977)

24. Managing Diversity and Glass Ceiling Initiatives as National Economic Imperatives USA Glass Ceiling Commission, (1995)

25. Mincer, J.: Schooling, Experience and Earnings. The National Bureau of Economic Research, New York (1974)

26. Mohan, N.J., Chen, C.R.: Are IPOs priced differently based upon gender? J. Behav. Financ. 5, 57-65 (2004)

27. Morris, B.: Trophy Husbands, Fortune Magazine, September 27 (2002)

28. Murphy, K.J.: Executive compensation. In: Ashenfelter, O., Card, D. (eds.), Handbook of Labor Economics. North Holland, Amsterdam (1999)

29. Polacheck, S.W.: How the Human Capital Model Explains Why the Gender Wage Gap Narrowed, IZA Discussion Paper Series, 1102 (2004)

30. Powell, M., Schubert, R., Gysler, M.: How to predict gender-differences in choice under risk: a case for the use of formalized models. Working Paper Center for Economic Research Swiss Federal Institute of Technology (2001)

31. Tittman, S., Wessels, R.: The Determinants of Capital Structure Choice. J. Financ. 43, 1-19 (1988)

32. Welbourne, T.M.: Wall Street likes its women: an estimation of women in top management teams of initial public offerings, Working paper 99-07, CAHRS/Cornell University (1999) 